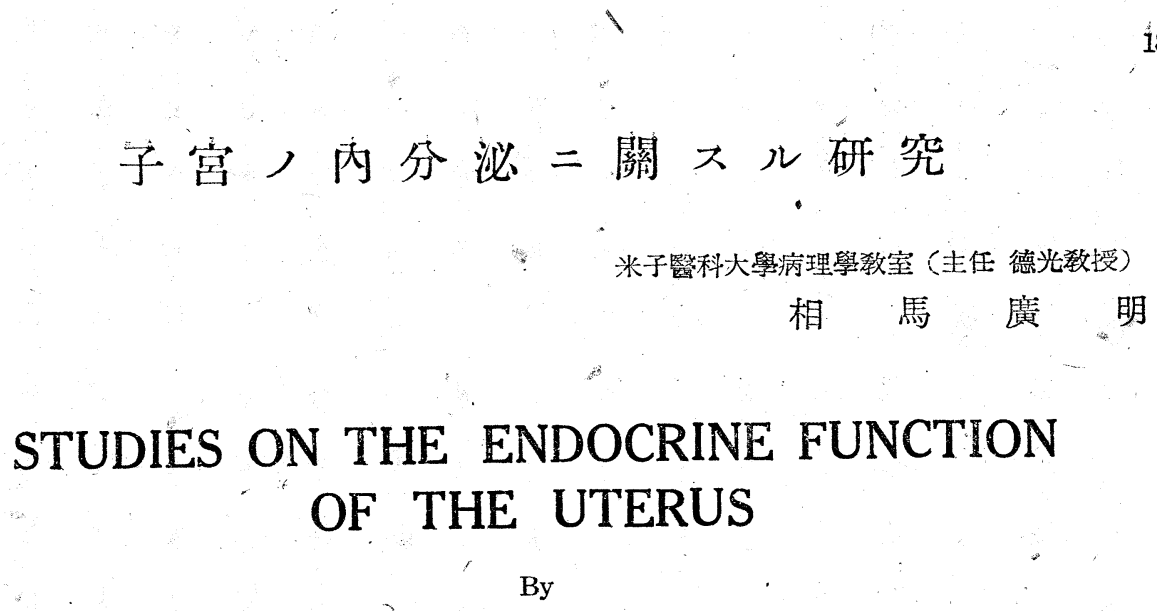

\title{
Hiroaki SoMA
}

(Director : Prof. Y. Tokumitsu)

(From the Pathological Dept:, Yonago Medical School, Tottori University)

The question of whether the uterus should be looked upon as an endocrine organ or not is inclined to be denied.

However, the writer has attempted to solve this question by series of experiments, in which he has injected the serum of the blood from the uterine vein of the rabbit irto the mice, and attempted to study the variability in the estrus cycle of the. mice and in the estrual effect of the folliculin by the existence of the uterus. Consequentiy he has dwelt on the existence of the endocrine of the uterus from the following results:

1) Soluble substance in organic solvent of the blood-serum from the uterine vein of the normal mature rabbit brings on the cantinuous estrus cycle of the mice, produces estrus in castrated mice and brings on the hypertrophia of the uterus. The active substance is also found in the uterine vein of the rabbit 3 days after castration, but is vanished in that of the castrated rabbit which has brought on the atrophia of the uterus passing 10 days, and it cannot be found in that of the young immature rabbit. The above active function has no effect in the ovario-hypterectomized mice, but when the uterus is retransplanted to these mice, it is revived. The active substance is soluble in alcohol, ther, acetone and chloroform.

2). The estrual effect of the folliculin in castrated mice is markedly increased by the mixture of the active substance in the uterine venous serum and distinctly differs by the existence of the uterus of the injected mice.

From the above experiments, it is evident that the uterus is a necessary reproductive, as well as an endacrine organ which produces a special hormone which stimulates the development of the uterus, regulates the estrus cycle co-jperating with the ovaries and harmonizes the metabolism of the ovarian hormone.

(Author's abstract)

\section{- 緒 文}

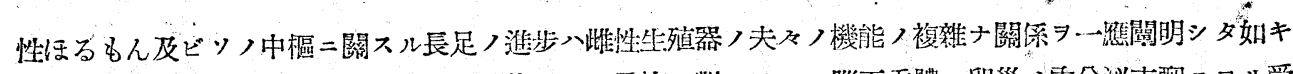
感ガアル。ソノ中デモ则巢卜最モ密接ナ連絡ニアル子宮二對シテハ，眨下琶體〜卵巢入內分泌支配二ヨル受 


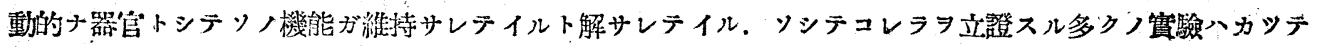

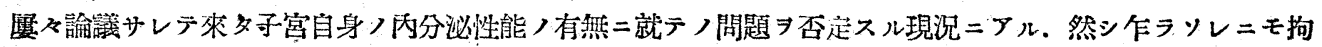

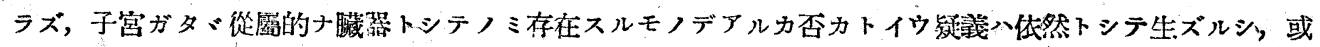

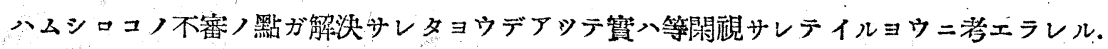

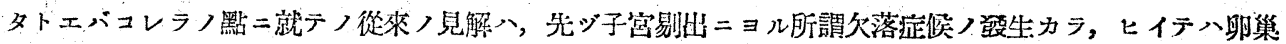

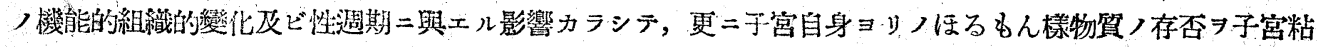

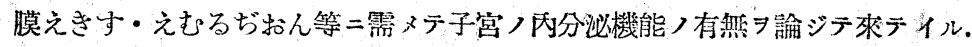

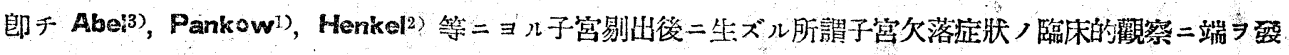

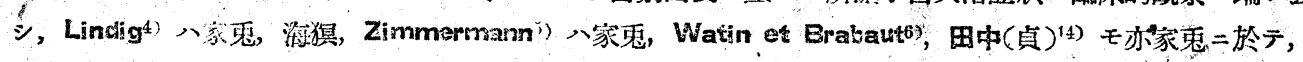

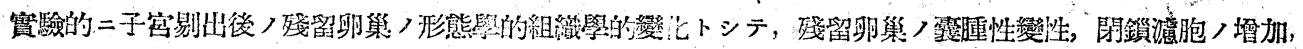

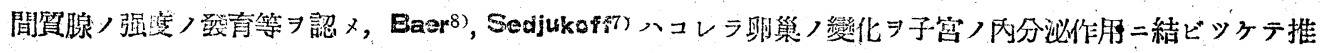
察シ タ. 然シ他方デ八 Grammatikati (3), Glaeveck ${ }^{34)}$, Mandi ,u. Bürger 5), Jakobsohn ${ }^{36)}$, Westmann ${ }^{3 i)}$

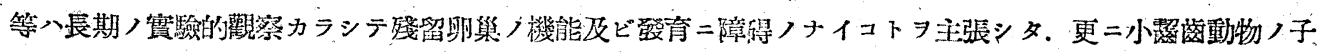

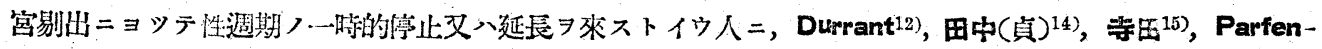
off10), Kok ${ }^{13)}$, Winter11) 等方アルガ，氏等八本變化 $ヨ$ 必ズシモ子管入內分泌作用三ョル積極的ナ現レノ結

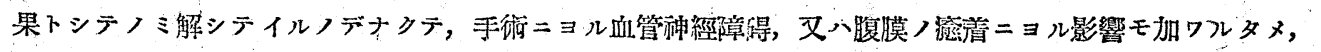

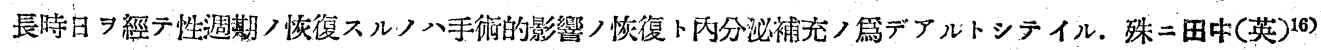

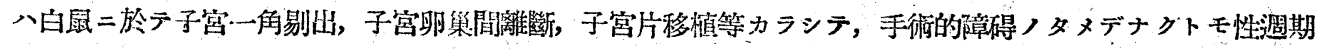

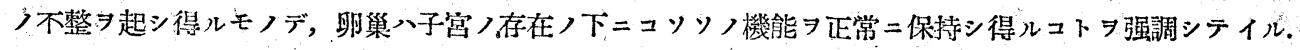

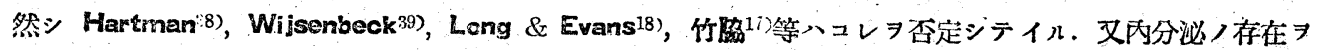

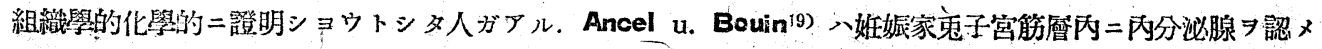

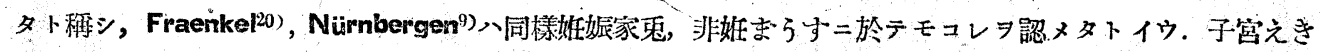

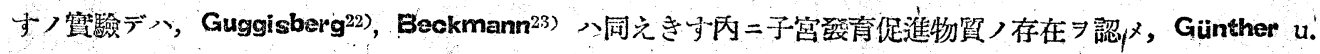

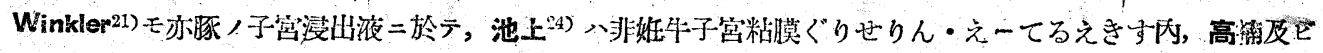

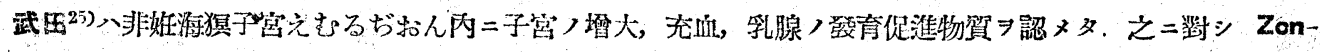

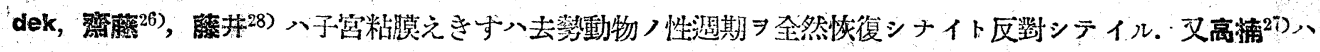

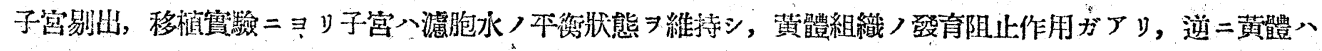

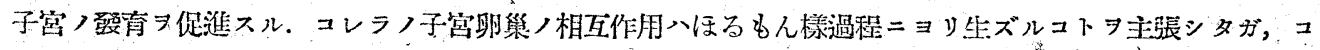

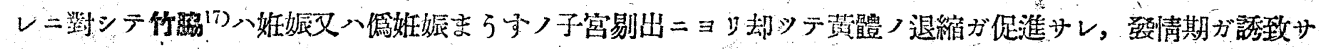

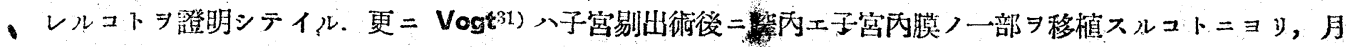

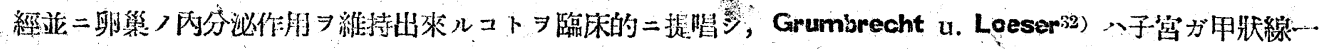

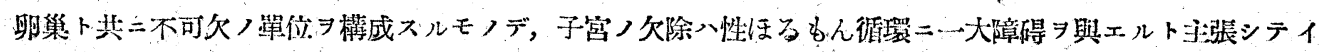
u.

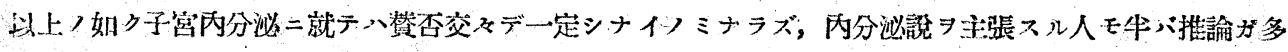

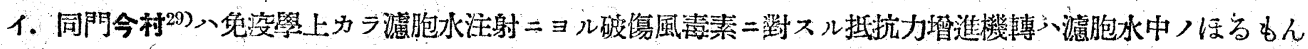

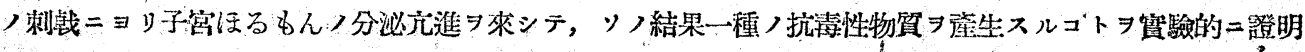

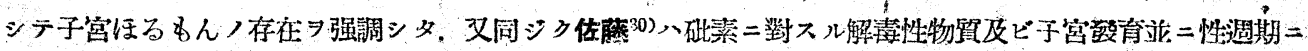

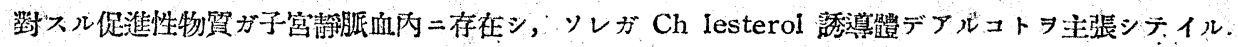

既二德光呚授40)八古クカラ藏器ノ內分泌作用 又八移植實驗 $シ ョ$ 制定

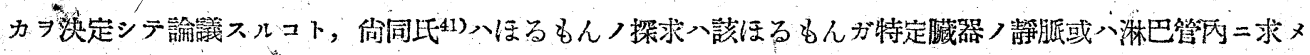

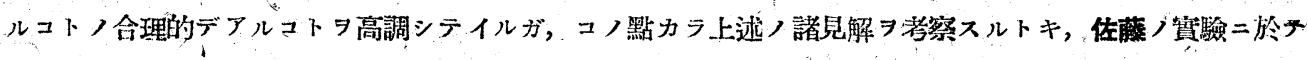


始メテ子管ノ內分泌二對スル見解ガ明ラカニナッタトイエヨウ.

(1)

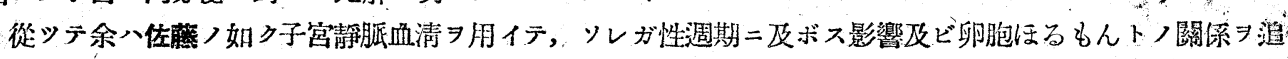
究スルコトニシツテ子宫內分泌ノ・端习知ロウト試ミタ。

\section{貿驗方針及ピンノ方法}

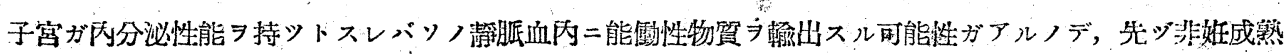

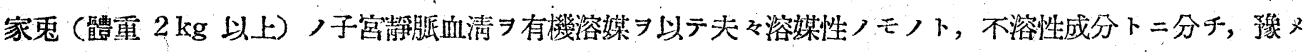

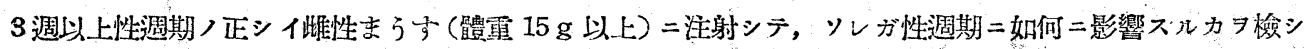

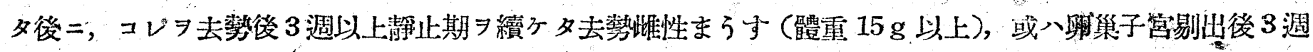
以上經過シタモノ，或入卵巢子宮剔出後子営移植 シシタまうす等ニ夫及背部皮下 $=$ 每日 1 回體重每 $10 \mathrm{~g} \times 0.2$

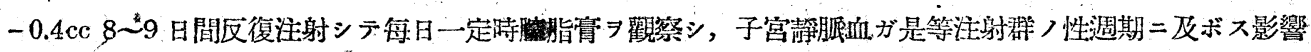

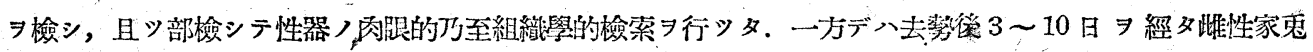

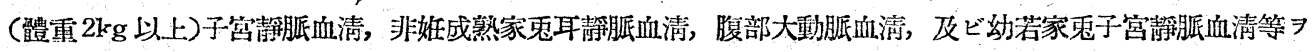
對照トシテ上記各群ノまうす性週期二反ボス影響フ憸ペタ.

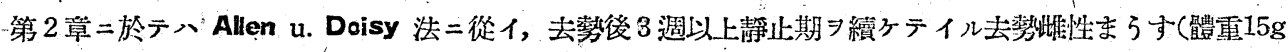

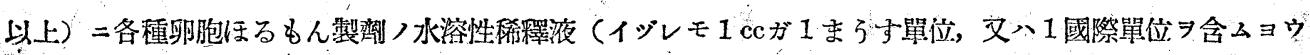

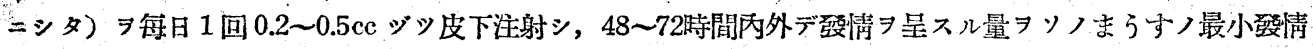

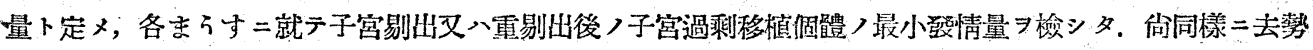

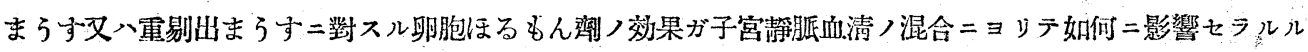
カシ雚勘シタ.

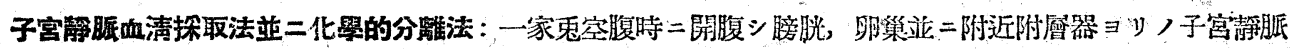

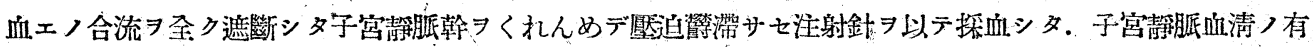
機溶媒分離法入于窝素胍血清 $=5$ 倍量ノ無水之一てる 7 加

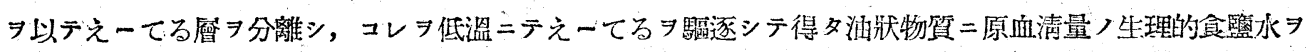

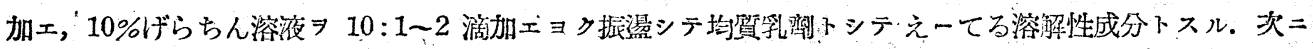
えーてる篔 モま万す體央每 $10 \mathrm{~g} \times 0.2 \sim 0.4 \mathrm{cc}$ 宛伐用シタ.

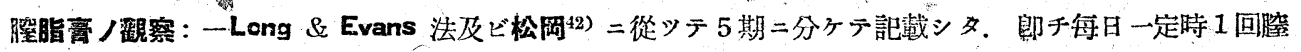

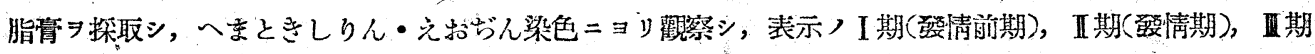
(登情後期 1)，W期( 發情後期 2)，V期( 静止期)及ビ各移行期トシタ.

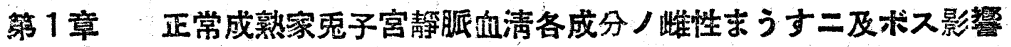

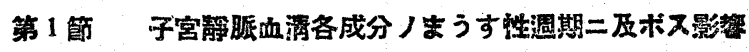

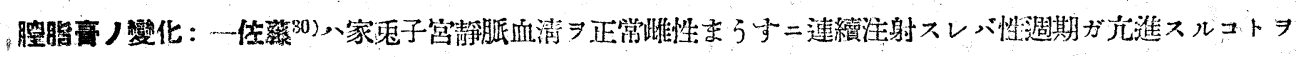

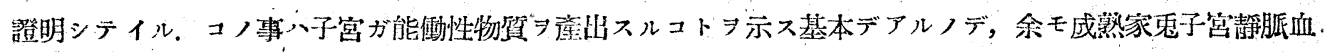
ガ正常まうすノ性蔨期二與エル影響ヨ確メヨウトシタ。

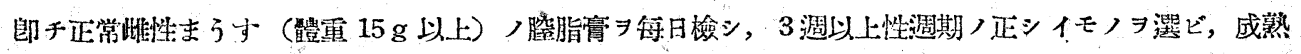

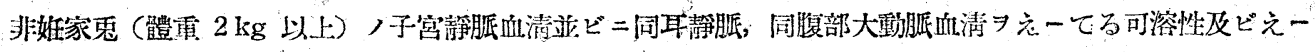

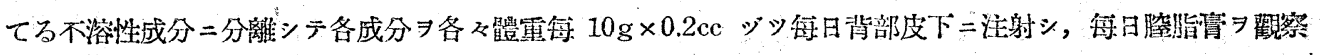
:3.

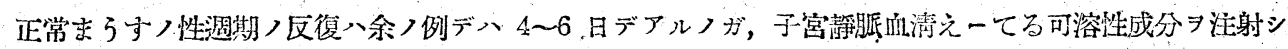

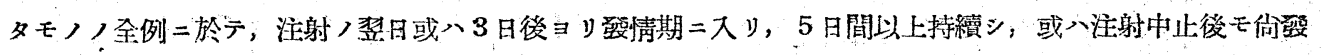




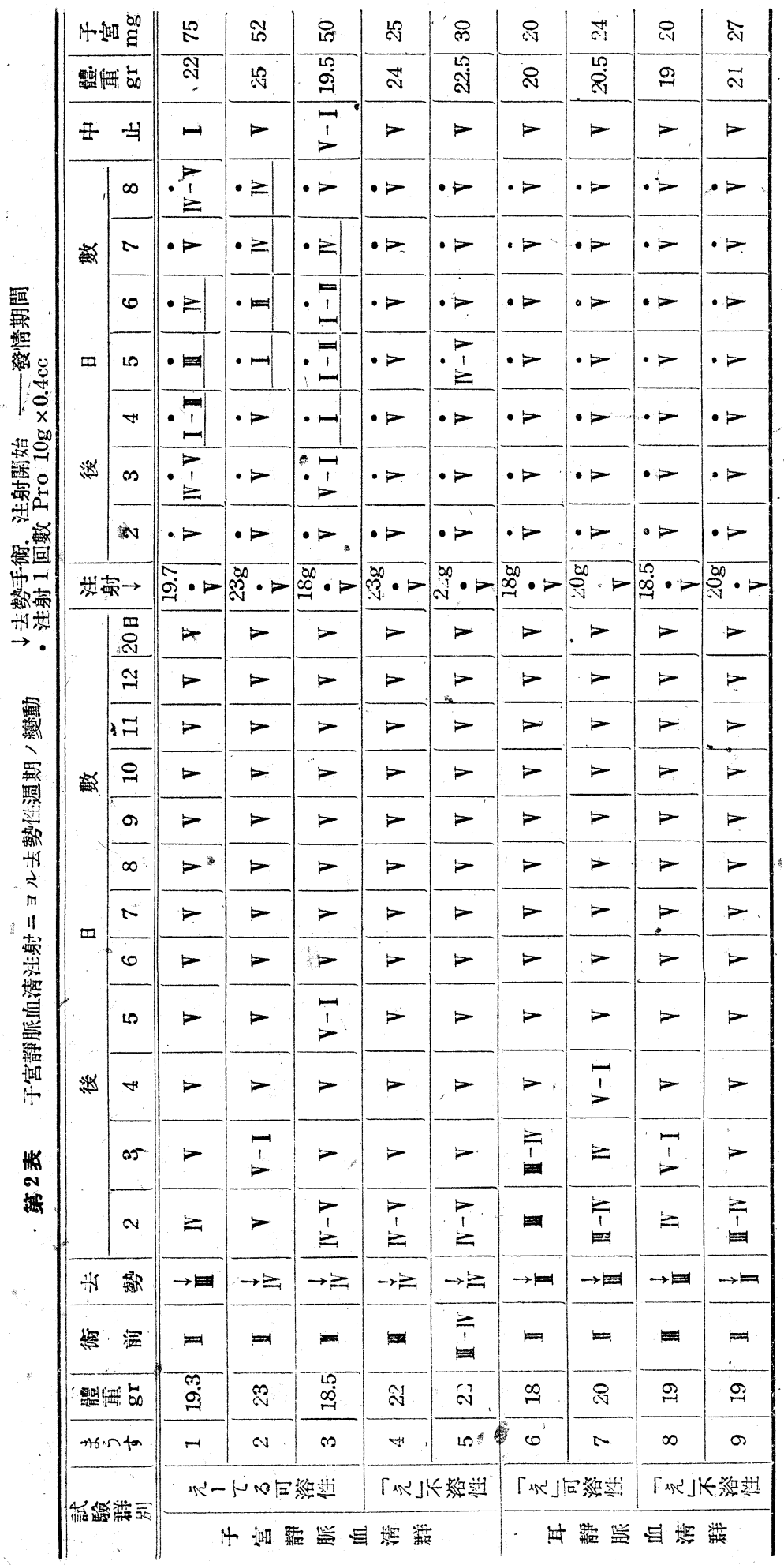

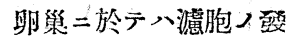
青分底好デ称二成熟卵胞 ヨ數個認メタガ, コレニ 区シテ莞體形成八極ク輕 微デアッタ. 血管ノ擴張 充血八中等度デアル，子 宮静脈血清之一てる不溶 性成分注射例，及ビ對照 トシテノ取敖挀，大動脈 血清各成分注射例デ八， 上記ノヨウナ子営ノ肥大 ヨ認メズ, 又卵緗二於テ

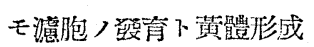
下>比入正常八組織侬力 ムシロ黄體化ノ傾向ガ强 ク見ラレタ.

本節ノ䡠驗カラ明ラカ 二子宮靜胍血清えーてる 可溶性成分八正常ま5す 性漕期 7 興舊サセ，子 赏〉登有习隹良ナラシメ ル働キノアルコトヨ知ツ タ:シカモ本物貿《閶》 一般流血中二存在スルモ

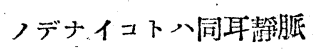
血二存在シナイコトデ制 リ, 且ツ動脈ヨ介シテ他

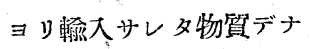
タコトハソレガ腹部大動 胍血內二㑇メラレナイカ ラデアル。

\section{第2 節 子宮静眽血渾 各成分ノ去㲛落うす 憆逼期二及ホスス影響}

前節ノ暂臉二基ジイテ

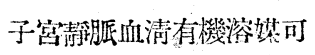
溶性成分方正常ま 5 す

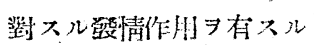
事カラ；該成分ノ中二泾縞

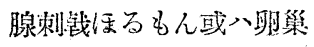
ほるもん類似八能働性物 質入存在ガ考エラレル。 此點二就テ值藤30) 八子宮 


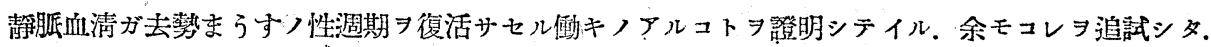

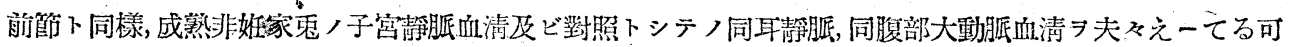
溶成分及ビ不溶成分二分離シテ，發情期ノ有無习確認シ

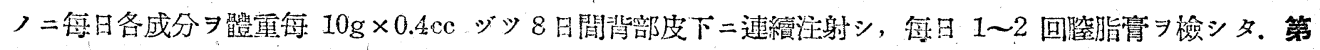

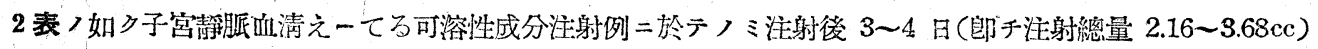

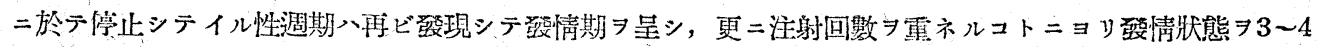

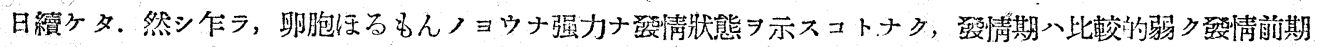

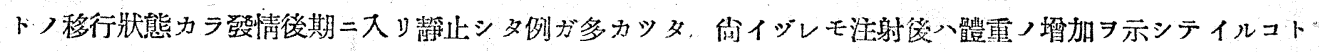

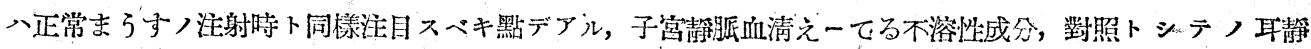
脈, 大動脈血清群二於テ六全然性週期ノ恢復习認メナカツダ。(第 2 表)

組織學的所見：ーイジレモ注射中止後直デ二剖檢シテ性器ノ肉跟的組織學的檢索习行ツタ. 份對照トシテ

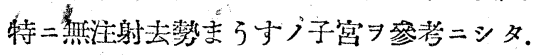

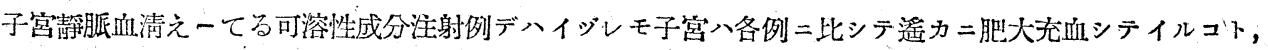

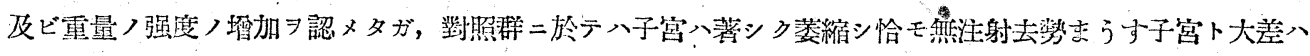

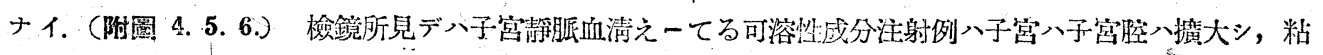

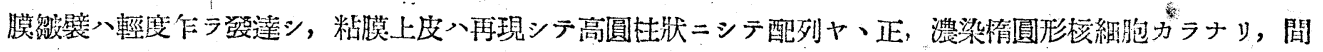

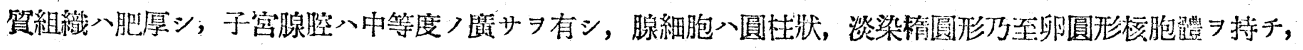

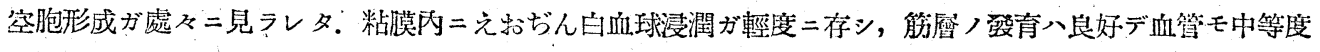

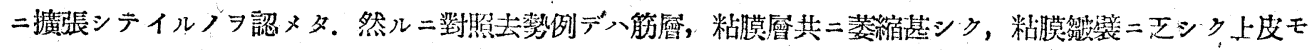
縮小シ核モ稍及漲染シ內腔モ陝イ。

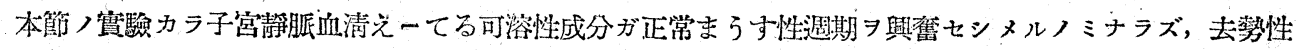

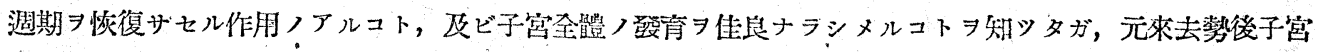

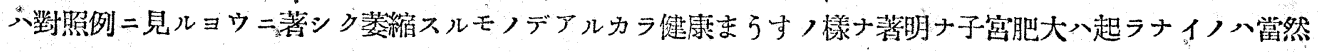

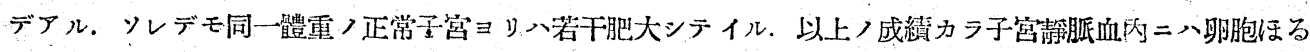
も儿類似ノ能働性物質, 存在习否定出來ナイト思ウ.

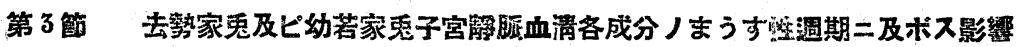

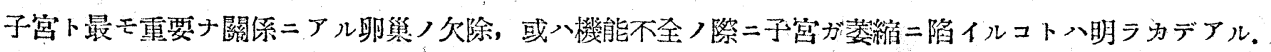

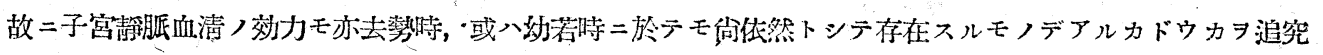

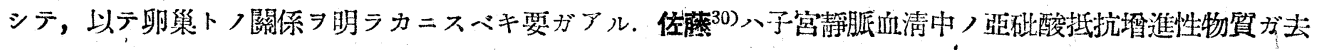

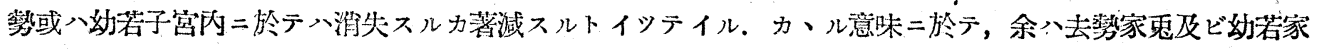

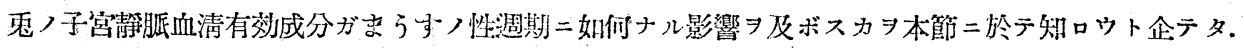

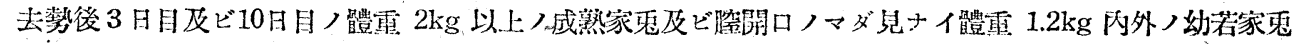

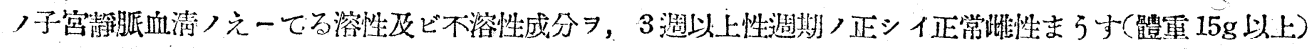

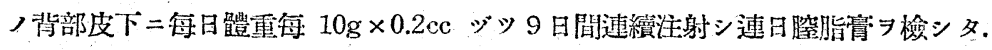

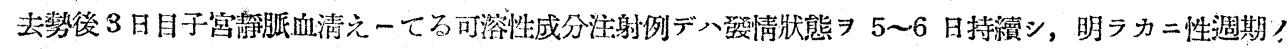

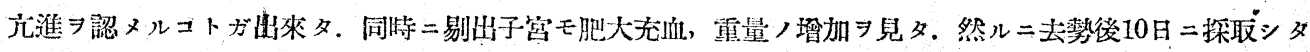

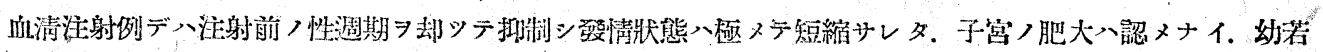

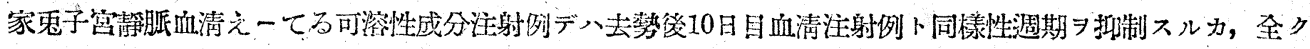

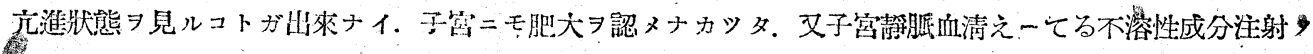

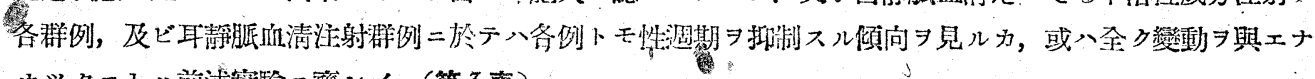
カッタコト八前述筫驗二齊シイ。(第了表)

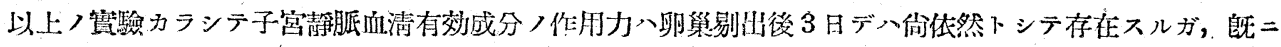


日本內, 分泌學會雜僖

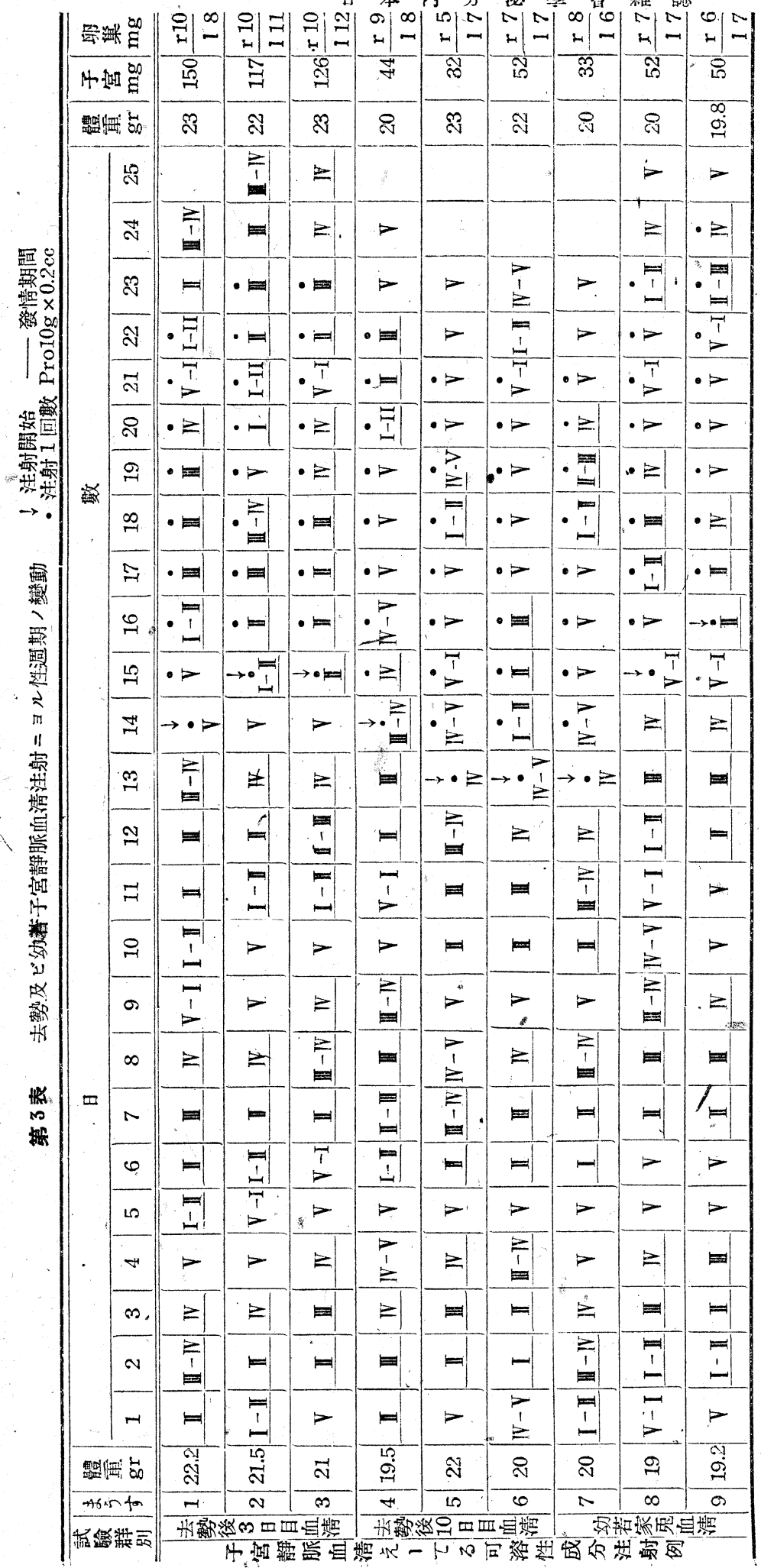

193

10 日 7 經テ子品方萎溦二 陷イルト同作用力八全》 消失シ，又卵集機能不全 デアル末熟家鬼デ八同樣 二作用力ガ減弱シ機能

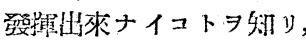
畉㙰子管卜>相互關係 八不仃欠ノモノデアルコ 下ヨ知り得タ, 換言スレ パ，成熟家鬼王管静胍血。 清中二ノミ有效物賀ノ存 在スルコトヨ確入得タワ ケデフル。

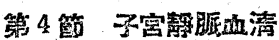 各成分ノ致鼻子宮㔀 出まうすニ及ボス影

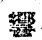

子宮籍脈血清えーてる 可跉性成分方卵胞ほる 几類似ノ作用 7 發揮スル 二當ツテ，特二該成分ガ イッ゙レノ臟器二對シテ侵 獎シ，ソノ作用力シ示ス カトイウ疑穿二對シテ， 余八本節二於テ卵巢卜卜 モニ子宾ラモ電剔出シテ 本成分八作用效果 7 知口 ウト企テタ。

第 2 節卜同樣成熟家鬼 子營靜胍血清及ビ同耳簿 脈, 大動胙血清ノえーて る可溶性成分及ビ不溶性 成分ヨ性週期ノ正シイま 5すノ卵粢及ビ子窝习同 時二重剔出シ，遮後 3 週 ヨ經テ體重モ恢復シ, 連 續篮止期 (體重 $15 \mathrm{~g}$ 以上) >背部皮 下二侮日 1 回體䨘每 $10 \mathrm{~g}$ $\times 0.4 \mathrm{cc}$ ・゙ッ 8 日間注射

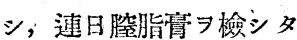
結果, 各血清各成分注射 例，全例二於于性涸期， 恢復 7 全然認メルコトガ 
'出來ナカッ夕. (表略)

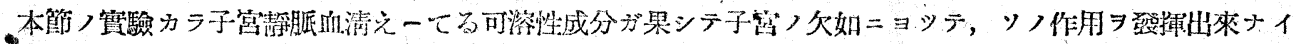

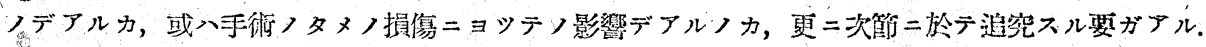

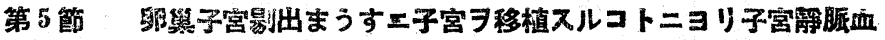 清肉/能働性物質ノ作用二美異习來スカ}

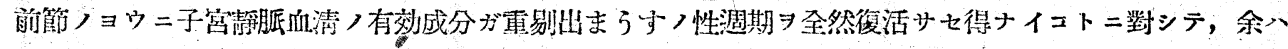

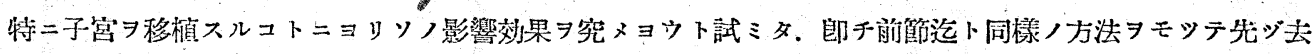

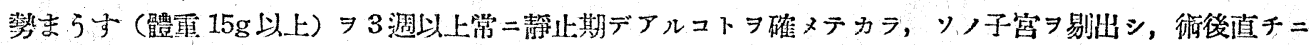

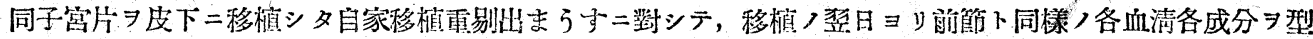

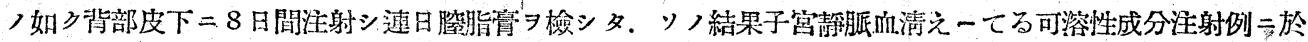

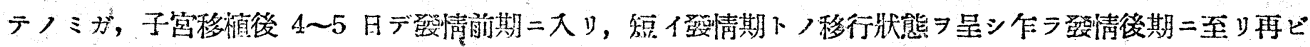

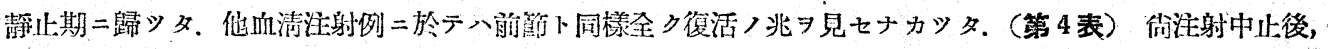

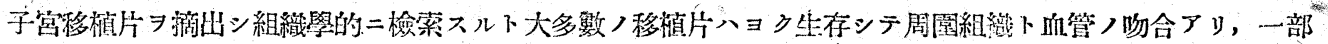

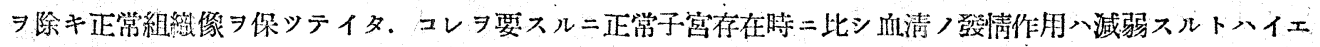

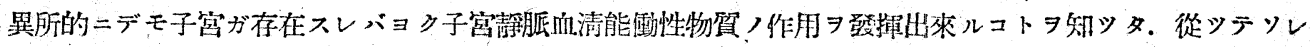

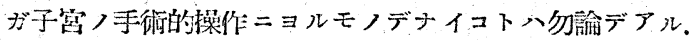

第 4 表 自家秋稙車剔出まうすノ變動 - 注射 1 回數 Pro $10 \mathrm{~g} \times 0.4 \mathrm{cc}$

\begin{tabular}{|c|c|c|c|c|c|c|c|c|c|c|c|c|c|c|c|c|}
\hline \multirow{2}{*}{\multicolumn{2}{|c|}{ 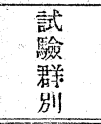 }} & \multirow{3}{*}{$\begin{array}{l}ま \\
5 \\
5 \\
\frac{1}{9}\end{array}$} & \multirow{3}{*}{ 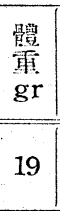 } & \multirow{3}{*}{$\frac{\begin{array}{c}\text { 去 } \\
\text { 勢 }\end{array}}{\stackrel{\downarrow}{\text { ll }}}$} & \multirow{3}{*}{ 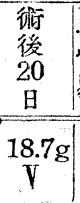 } & \multirow{3}{*}{$\frac{\begin{array}{c}\text { 子出 } \\
\text { 富移 } \\
\text { 剔植 }\end{array}}{\frac{\downarrow}{V}}$} & \multirow{3}{*}{$\frac{\left|\begin{array}{c}\text { 注開 } \\
\downarrow\end{array}\right|}{\dot{\mathrm{V}}}$} & \multicolumn{4}{|c|}{ 日 } & \multicolumn{3}{|c|}{ 数 } & \multirow{3}{*}{$\begin{array}{l}\text { 中 } \\
\text { 止 } \\
\text { V }\end{array}$} & \multirow{3}{*}{ 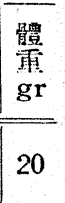 } \\
\hline & & & & & & & & 2 & 3 & 4 & 5 & 6 & 7 & 8 & & \\
\hline \multirow{5}{*}{$\begin{array}{c}\text { 子 } \\
\text { 宮 } \\
\text { 静 } \\
\text { 脈 } \\
\text { 血 } \\
\text { 清 } \\
\text { 群 }\end{array}$} & $\begin{array}{l}\hbar \\
1\end{array}$ & & & & & & & $\dot{\mathrm{V}}$ & $\dot{\mathrm{V}}$ & $\mathrm{V}-\mathrm{I}$ & $\mathrm{I}-\mathrm{I}$ & $\mathrm{H}-\mathrm{IN}$ & $\dot{\mathrm{V}}$ & $\dot{\mathrm{V}}$ & & \\
\hline & \multirow{2}{*}{$\begin{array}{l}\frac{1}{\tau} \\
\text { 而 } \\
\text { 溶 } \\
\text { 抄 }\end{array}$} & 2 & 18 & $\stackrel{\downarrow}{1}$ & $\begin{array}{c}18.5 \mathrm{~g} \\
\mathrm{~V}\end{array}$ & $\stackrel{\downarrow}{\mathrm{V}}$ & $\dot{\mathrm{V}}$ & $\dot{\mathrm{V}}$ & $\dot{\mathrm{V}}$ & $\mathrm{V}-\mathrm{I}$ & I-II & iv & $\dot{\mathrm{V}}$ & $\dot{\mathrm{V}}$ & $\dot{\mathrm{V}}$ & 19 \\
\hline & & 3 & 19.5 & $\underset{d}{\downarrow}$ & $\frac{19 g}{\mathrm{~V}}$ & $\stackrel{\downarrow}{V}$ & $\dot{V}$ & $\ddot{\mathrm{V}}$ & $\dot{\gamma}$ & $\dot{\mathrm{V}}$ & $\dot{I}$ & I-I & IV $-\mathrm{V}$ & $\dot{\mathrm{V}}$ & $\mathrm{V}$ & 20 \\
\hline & \multirow{2}{*}{ 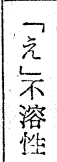 } & 4 & 18 & $\stackrel{\downarrow}{\text { IV }}$ & $\underset{\mathrm{V}}{18.4 \mathrm{~g}}$ & $\stackrel{\downarrow}{V}$ & $\dot{V}$ & $\dot{\mathrm{V}}$ & $\dot{\mathrm{Y}}$ & $\dot{V}$ & $\dot{\mathrm{V}}$ & $\dot{\mathrm{V}}$ & V & $\dot{\mathrm{V}}$ & $\mathbf{Y}$ & 19 \\
\hline & & 5 & 20 & $\underset{\downarrow}{\downarrow}$ & $\frac{21 \mathrm{~g}}{\mathrm{~V}}$ & $\stackrel{b}{\dot{V}}$ & $\dot{\mathrm{V}}$ & $\mathrm{V}$ & $\dot{\mathrm{V}}$ & $\dot{\mathrm{V}}$ & $\dot{\mathrm{V}}$ & $\dot{\gamma}$ & $\dot{\mathrm{V}}$ & $\dot{V}$ & $\mathrm{~V}$ & 21.2 \\
\hline
\end{tabular}

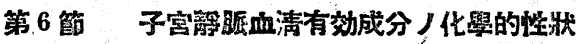

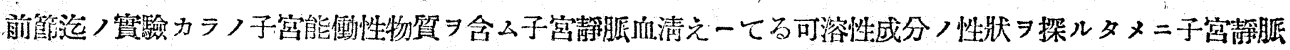

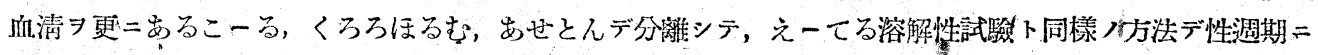
與エル作用 $习$ 迤究シタ.

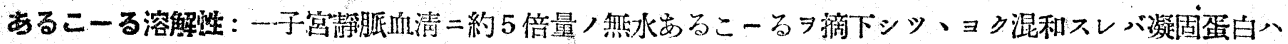

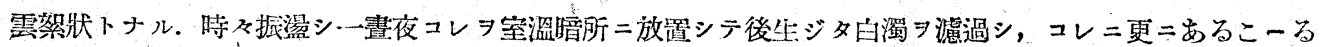

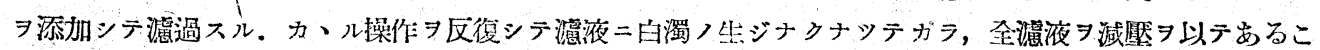

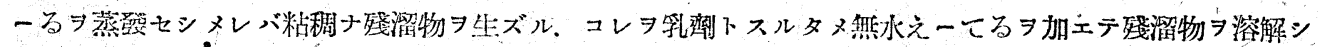

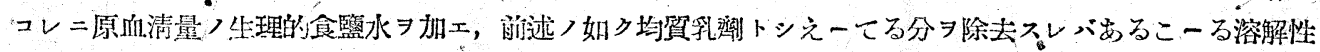

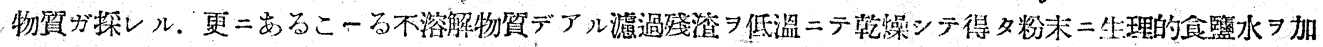

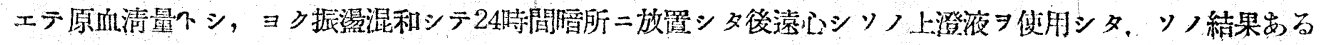




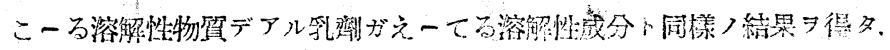

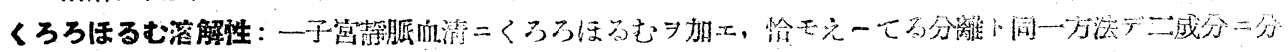

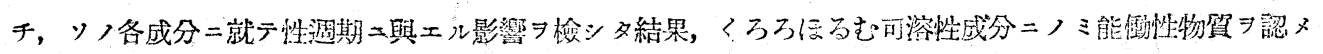
夕.

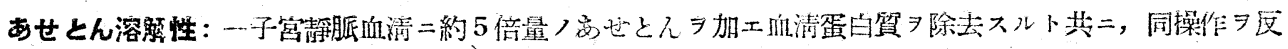

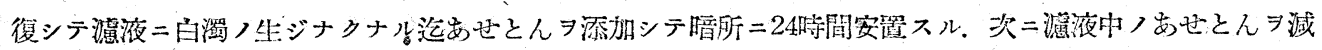

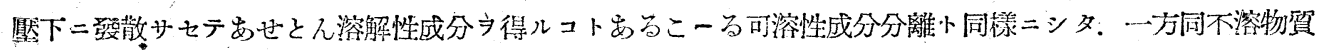

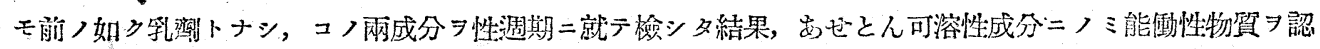
又得及.

\section{本䓥ノ小括}

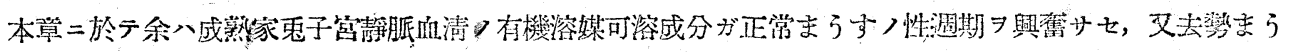

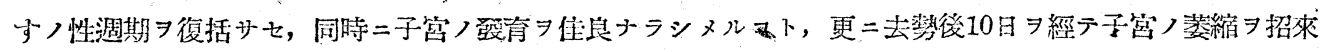

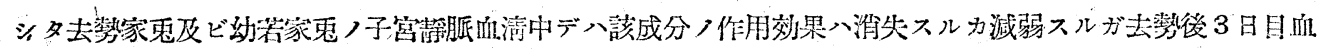

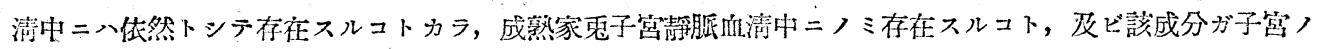
欠除ニヨツテ作朋ノ發現

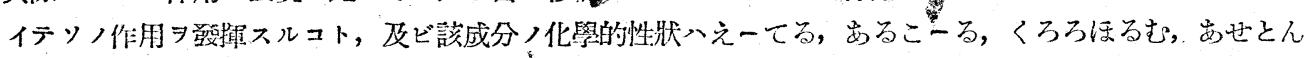

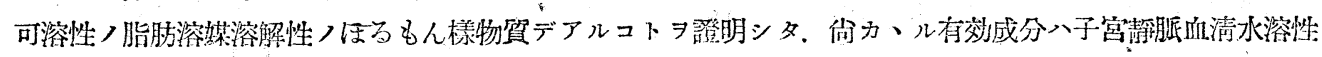

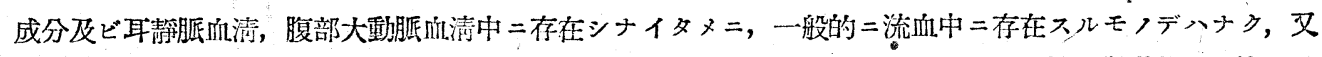

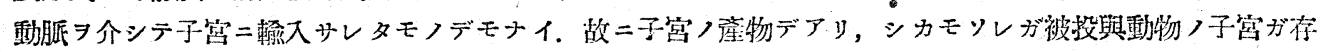

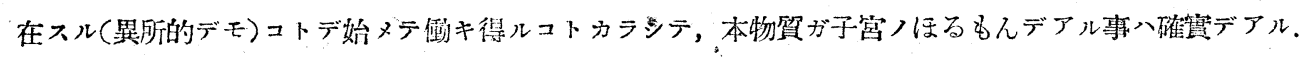

\section{第 2 章 卵胞ほるもんト子宮丙分泌トノ關係}

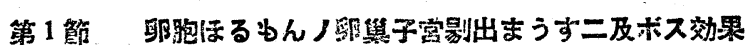

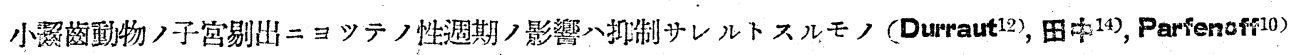

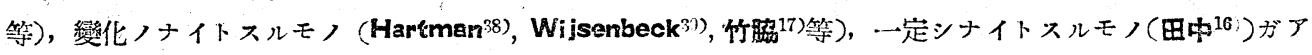

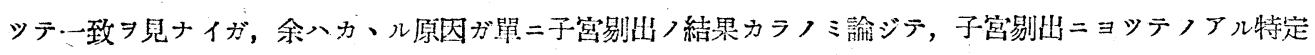

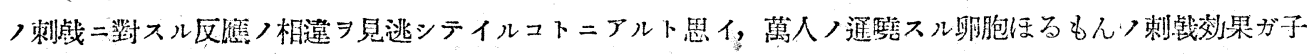

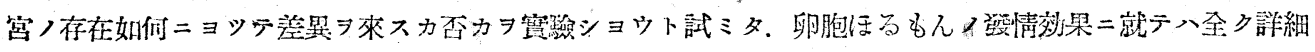

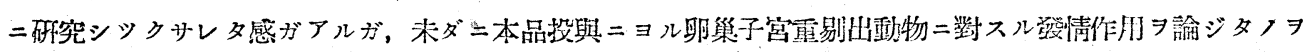

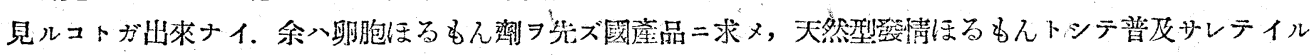

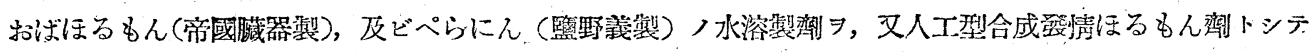

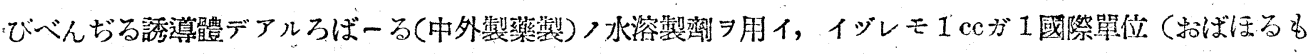

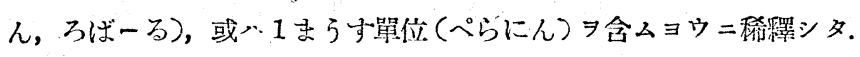

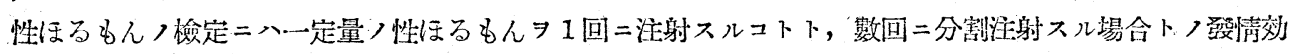

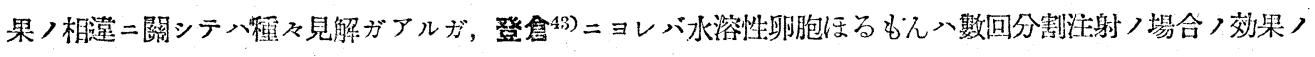

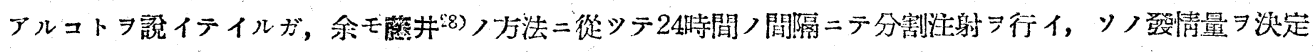

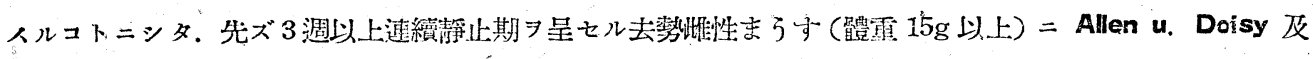

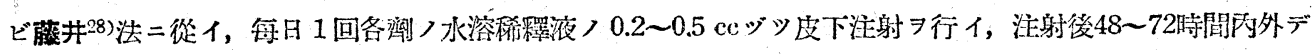

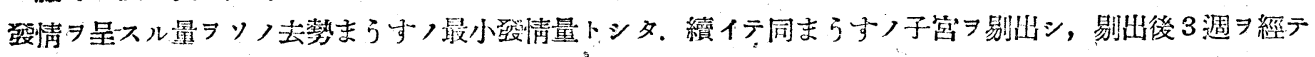

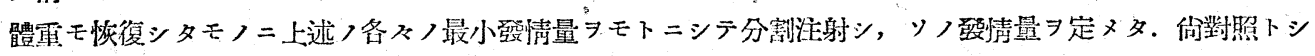

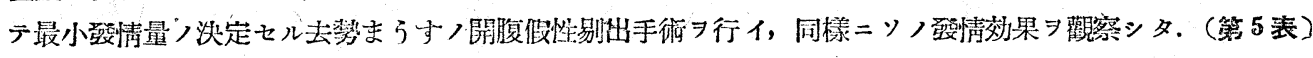

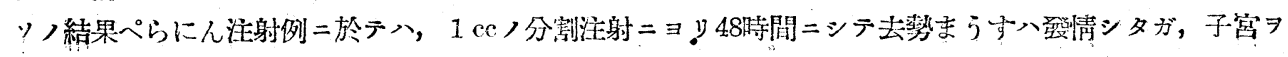




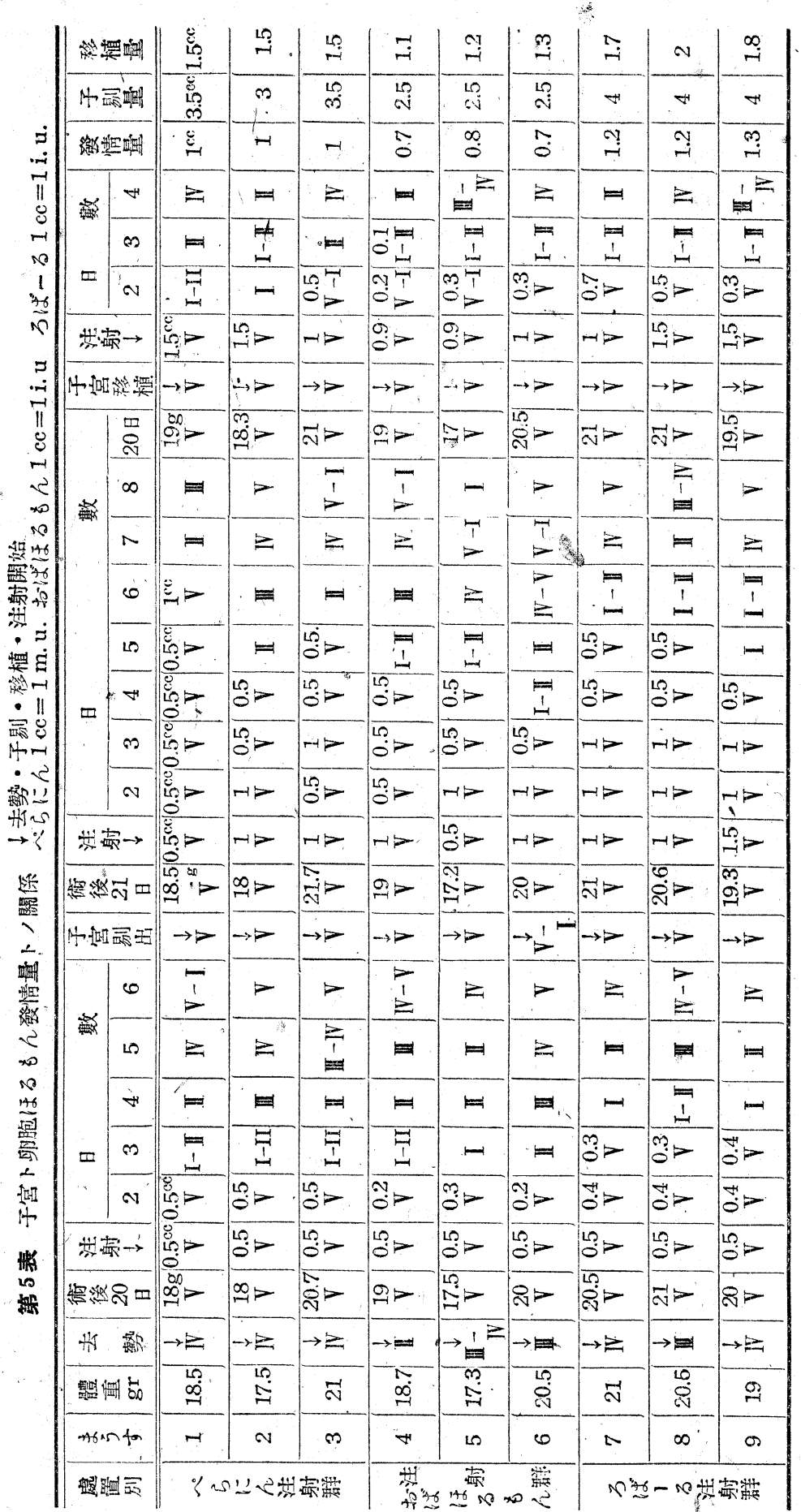

剔出シタ際ニハ $3 \sim 3.5 \mathrm{cc}$ 习分微往射スルコトニヨ 》，然毛倘 1 回注射最 偣加シテ用イター拘ラズ 注射㷋 96〜144 時間ニシ テョウヤク發情狀態テ入 ツ夕。要下儿二子管剔出 ノ場合八最小發情量ノ 3 〜 3.5 倍量习要スルコ下 ニナル。刿ばぼるもん注

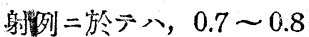
$\mathrm{cc}$ 八分割注射 $=\exists$ リ48時 間ニシテ去勢まうす發学 情スルガ, 子管习剔出ス ルコト $=ヨ . リ 2.5 \mathrm{ce}$ 八分 割注射 $尹$ 要シ, 1 回量 倍加シテ用イタ二拘ラズ 72〜96時間ニシテ登情ス ル二至ツ夕，即于, 最小 發情量ノ約 3 3.5倍量 7 要スルュトニナル。 ろば 一万注射例二於テ八 1.2 $\sim 1.3 \mathrm{cc}$ /分割注射 $=$ = リ76時間ニシデ去勢まう 守八發情狀態ニ入ッタガ 子管习剔出スルコトニヨ y $4 \mathrm{cc}$ >分割注射 要 然モ 1 回量 $习$ 倍加シテ注 射シター拘ラズ, 96〜130 時間デ濑》發情スル二至 ッタ。要スル二最小聚情 量>約 3.5 倍量 コトニナル。向對照，開 復做性剔出去學ま 万すデ ハイジレモソノ最小登情 量卜變ラナカッタ。

故二本鴊カラ明ラカー 卵胞ほるもん, 聚情量入 子管习剔出スルコト

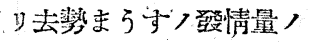
3〜3.5 倍量习雪スルコト

习知ツタ。 


\section{第 2 節 目剔出後ニ子宮移植ヨシタまうずニ卵狍ほるもん投與ノ效果}

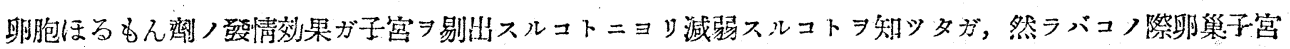

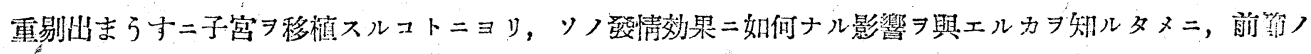

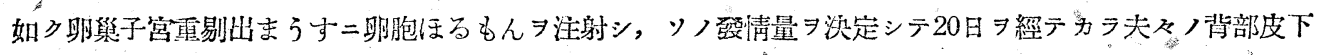

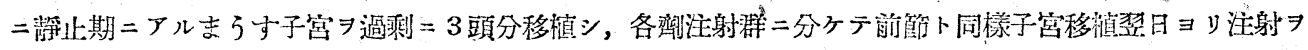
試ミタ．(第 5 表)

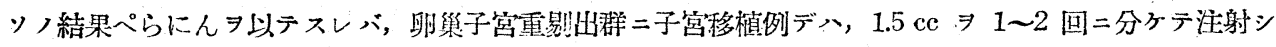

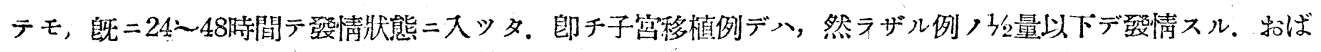

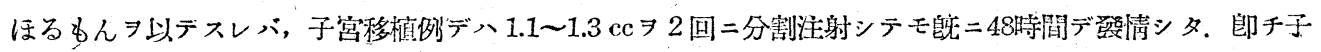

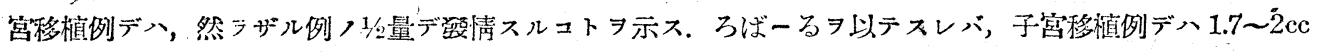

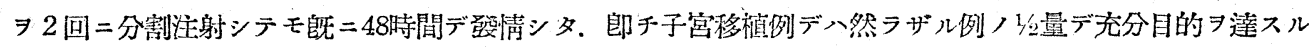
モノデアル.

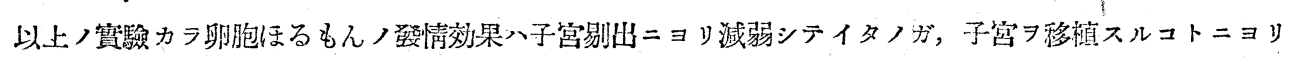

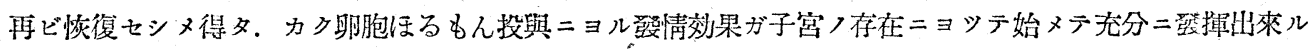

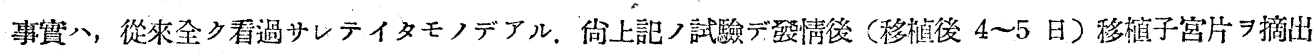

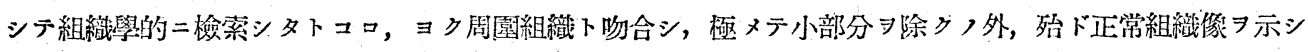

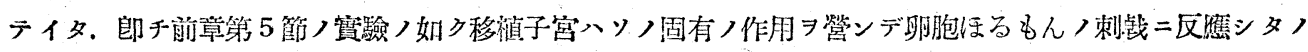
カ, 或八吸收サレタ完全ナ移植片ノ有效物質ト協カシテカ、ル性能习發揮シタカト若エル。

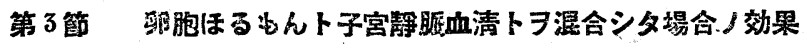

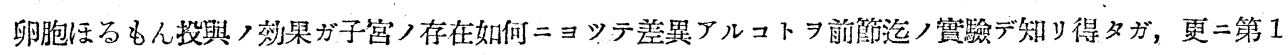

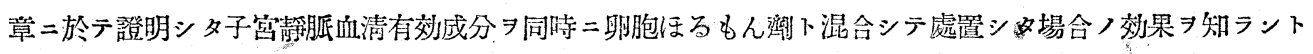
シタ.

前節汽卜同樣二去樊後 3 週静止期

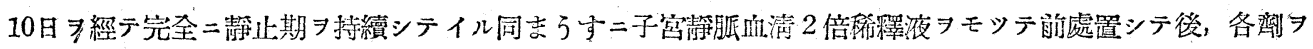

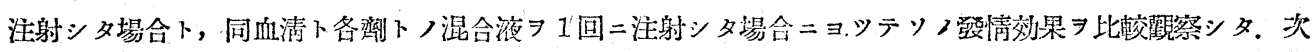

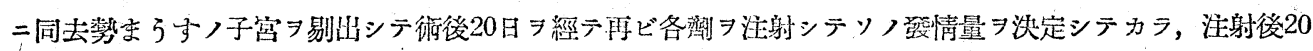
日後子宮静胍血清卜ノ混和注射

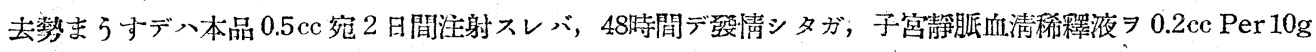

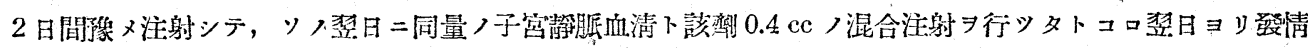

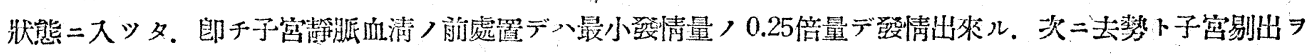

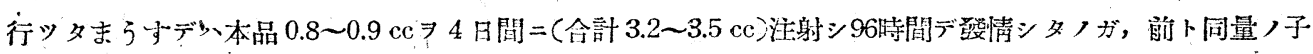

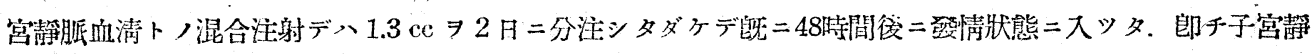

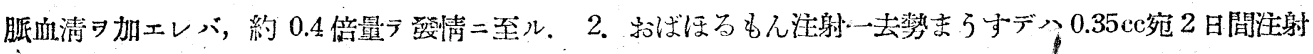

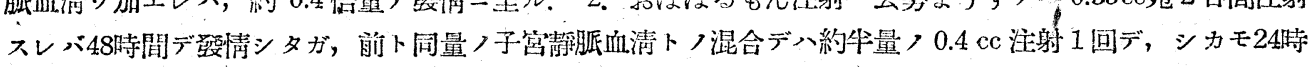

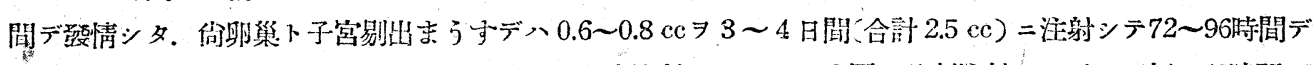

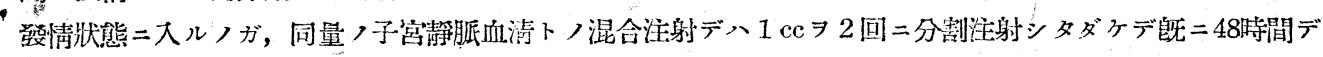

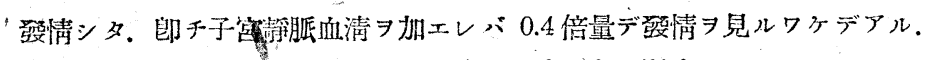

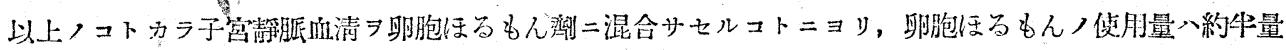

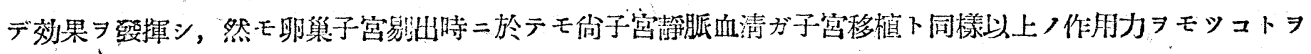
知得交.

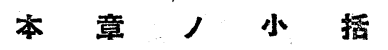




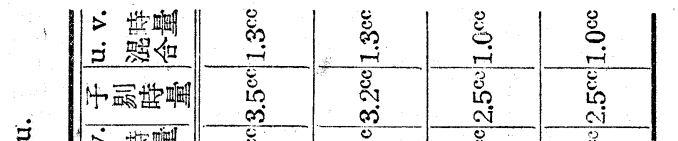 i. \\ $\rightarrow$ III \\ एं \\ $x \rightarrow$ \\ 本章二於テ八去樊まうす二對スル卵胞ほるるん，

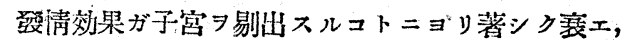 子窝ヨ移植スルコトニヨリ再ビ恢復シ, 更二子宮静 脈血淸注射/前處置及ビ混合シテ用イルコトニヨリ 著シクソノ墢情力方昂進スルコト \\ 總括及ビ考按}

at:

का

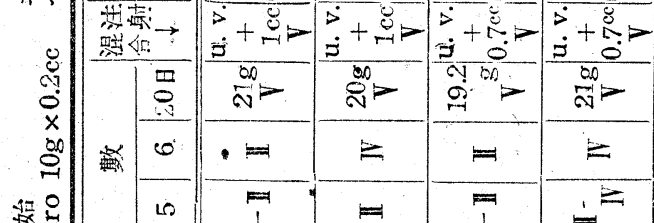

觜

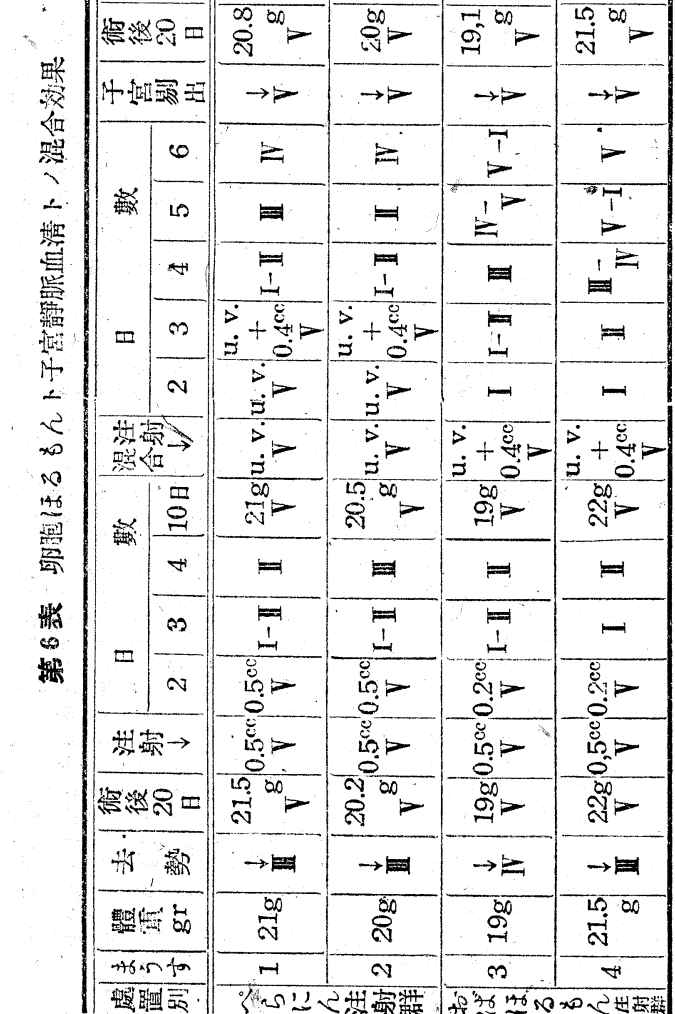

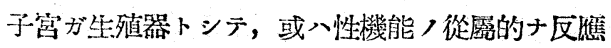
器官トシテノミ存在スルモノデアルカ; 或八獨自ノ 內分泌機能习持ツカトイウ疑㩆對シテ，余八第一

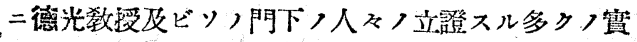

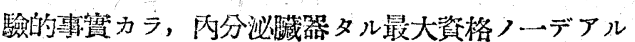
子宮ガ童生スル特殊能偅性物資, 出現 7 當該荿器静

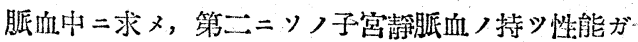

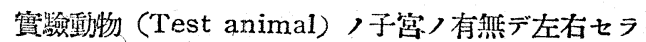
レルカ不カヨ檢シ，第三二去樊まうす二對スル卵胞

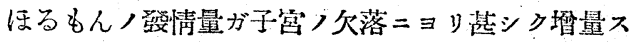
ルノミナラズ，子管静脈血ノ混会ニヨり變化シ得ル ヤ否カヨ檢討シタ。ソノ結果第 1 音二於テ正常成熟

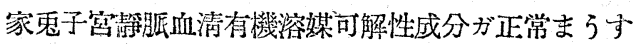

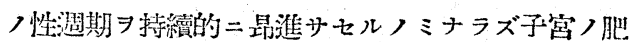

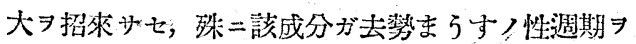
復活サセ儿働キフアルコトカラ卵胞ほるもん二似タ 性能ヨモッモノデアルコトガ制ル。而モカ、ル作冽” ガ耳清胍血, 動脈血中二存在シナイコトシ知ツタガ, コ 等賽…般流血中二普遍的二該成分ガ存在シナ イコト，及ビ動胍血・り翰入セラレタェノデナイコ

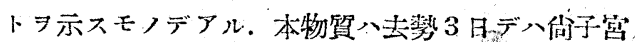
䝑脈血內二澄明シ得ルガ，10日 ヨ經テ子㸃〉萎縮 來セバ涓失スルコト，及ビ㭃若子宮二於テ八著シク

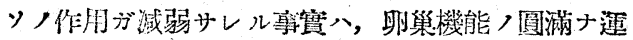
行方アッテ始メテ子窝カラ產生サレルコトヨ意味ス ル. 元來各內分泌臟器, 剔出 $=ョ$ り當喰ほるるんガ 流血中カラ消失スルハ 24 時間习出ナイモノデア

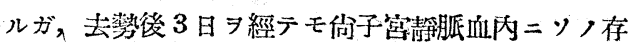
在示スコトメ夫ガ明ラカニ留胞ほるもんデナイコ ト・登明出來儿。第二二本物質，作用機轉方子窝 剔出スルコトニヨリ消失シ，子営习異所的二デモ移 植スルコトニヨり再現スルコト率, 子宮, 存在ナク

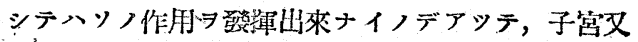
ハソノ有效成分二直接動イテカ、ル機能

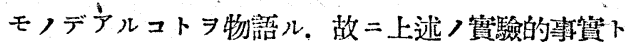

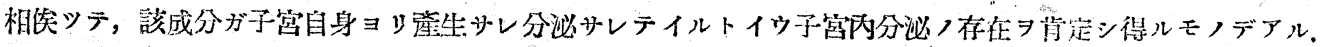




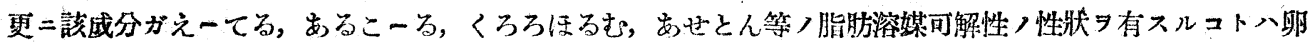

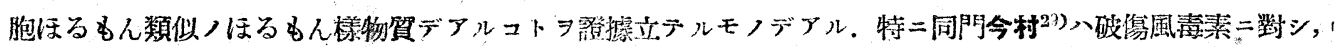

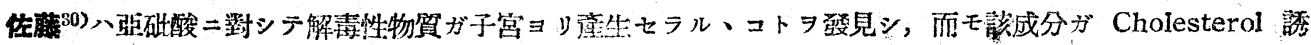

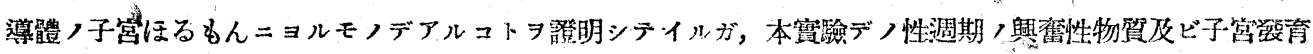
促進物貿ノ化學的性狀下相似シティル。

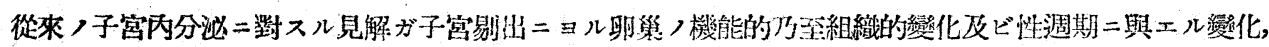

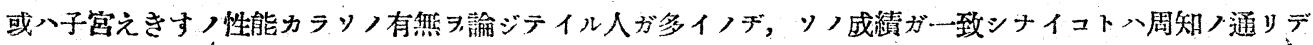

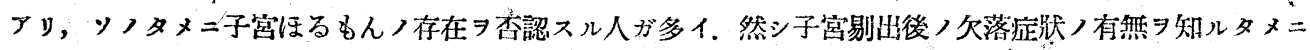

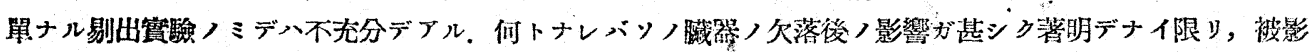

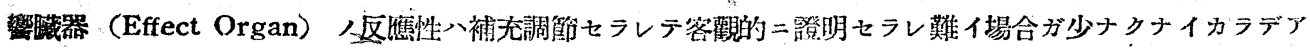

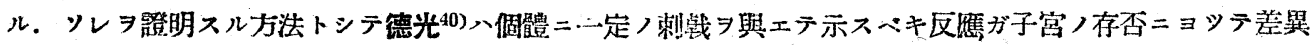

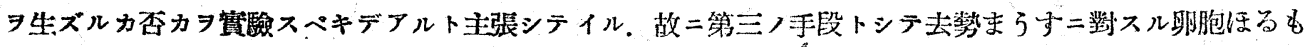

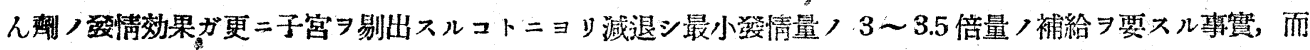

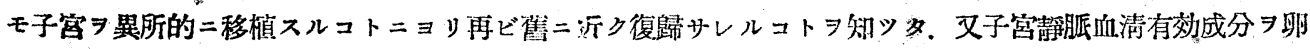

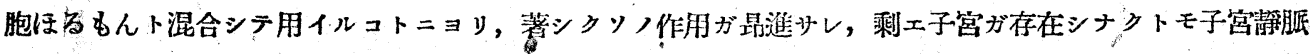

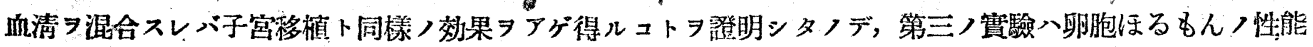
ヨ現ワスタメ二八子管〉健存, 珠二同ほるるんガ重大ナ影響习與エルモノデアルコトシ知り得タ。

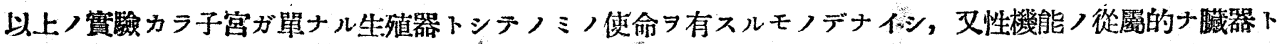

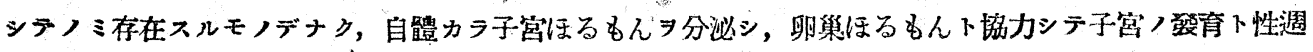

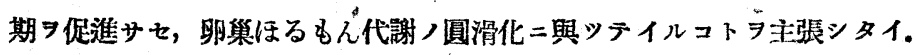

\section{結論}

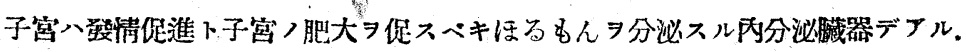

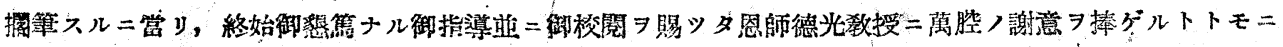
併而種々御敉示御鞭撻

\section{ま要 文 献}

1) Pankow: Zbl. f. Gyn. 1910, S. 427.

2) Henkel: Zbl. f. Gyn. 1904, S. 401. Münch. Med. Wschr. 1911. 58.

3) Abel: Arch. f. Gyn, 57 Bd. 1899. S. 261.

4) Lindig: Arch. f. Gyn. 117 Bd. 1922. S. 289. 120 Bd. 1923. S. 233.

5) Zimmermann: Arch. f. Gyn. 134 Bd. 1928. S. 328. 6) Watin et Brabaut : pef. Ber. Geburtsh. 23. 1933. S. 114.

7) Sedjukoff: Arch. f. Gyn. 118 Bd. 1923 S. 560.

8) Baer : Med. Klin. 1917. S. 752.

9) Nürnberger : Zbl. f. Gyn. 1922. S. 606 . 10) Perfenoff: Monatsch. f. Geb. u. Gyn. 88 Bd. 1931. S. 423.

Winter: Arch. f. Gyn. 150 Bd. 1932. S. 602.

12) Durrant: Am. J. Physigl. Vol. 76, 234, 1926. 13) Kok: Arch. f. Gyn. 141 Bd. 1930. S. 255.

14）田中贤夫：日娽會誌。26空，昭 6 .

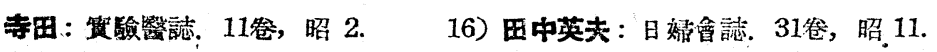

䟎. 286 , 昭 22 .

18) 10

Fraenkel $\exists y$ 引用.

20) Fraenkel : Arch. f. Gyn. 99 Bd. 1913.

Zbil. f. Gyn. 1932. S. 1868.

22) Guggisberg: Zeitschr. Geb. 75 Bd. 1913.

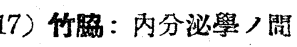

19) Ancel u. Bouin :
24) 池上: 日新镉學. 11密，大 10 .

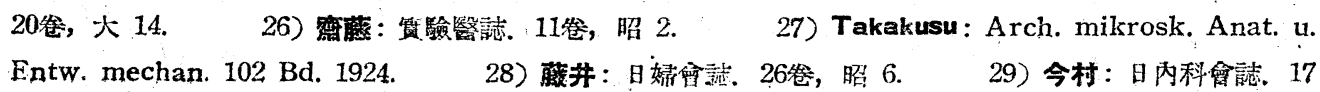




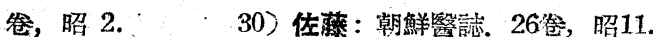

32) Grumbrecht u. Lceser : Arch. f. Gyn. 118 Bd. 1939.

Bd. $1889 . \quad 34$ ) Glaeyeck : Arch. f. Gyn. 35. Bd. 1889
31) Vogt: Münch. Med. Wochsch. 1941. 33) Grammatikati : Zbl. f. Gyn. 35 35) Mandl u. Bürger : ref. Monatschr. f. Geb. u. Gyn, 20 Bd. 1904.

Westmann: Zbl. f. Gyn. 1929. S 2578.

36) Jakobsohn : Zbl, f. Gyn. 1914.

S 1014.

38) Hariman: Am. J. Anat. Vol. 35. 1925.

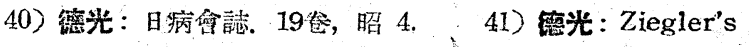

Wijsenbeck: ref. Ber. Geb. 13, 1928.

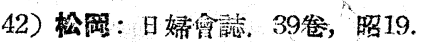

43) 登倉:

日婦會新. 29卷, 昭9. 


\section{相馬諭文附圖}

(1)

$$
\begin{gathered}
\text { 第 } 1 \text { 段 子宮靜 } \\
\text { 脈血清え一七 } \\
\text { 万可溶性成分 } \\
\text { 注射まうす子 } \\
\text { 宮 } 150 \mathrm{mg}
\end{gathered}
$$

第 2 段 同上 え一てる不溶 性成分注射ま 5す子宮 $70 \mathrm{mg}$

第 3 段 耳静脈 血清え一てる 可溶性成分注 射まうす子宮 $48 \mathrm{mg}$

第 4 段 同上光 一て万不溶性 成分注射夆了 す子宮 $52 \mathrm{mg}$

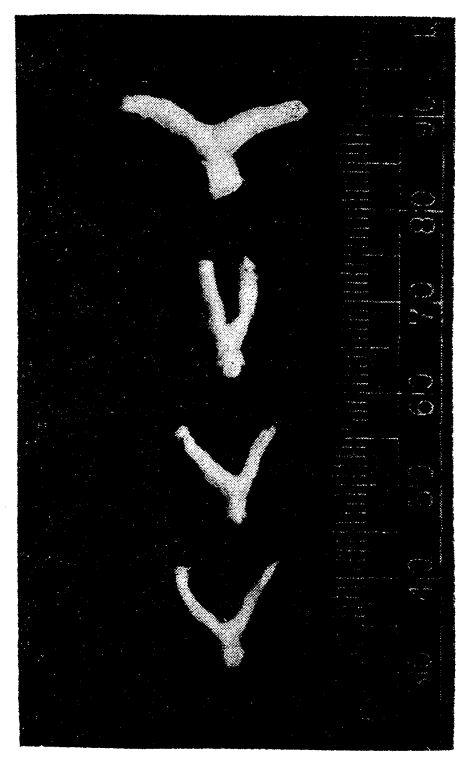

(2) (114倍揣大,

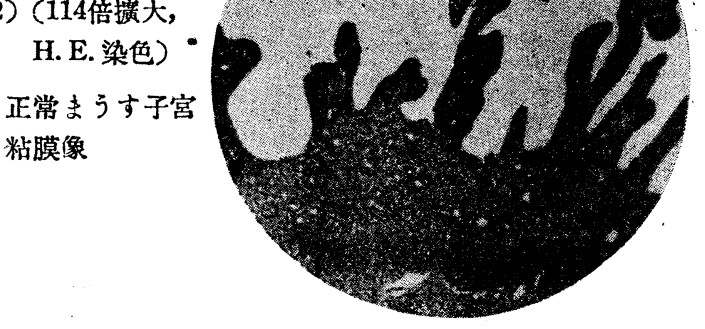

(3) (114倍撗大, H. E. 染色)

子宮静脈血清え 一て万可溶性成 分注射まうす子 宮粘膜像
(4)

$$
\begin{aligned}
& \text { 上段 子宮静脈 } \\
& \text { 血清え一てる } \\
& \text { 可溶性成分注 } \\
& \text { 射去勢まうす } \\
& \text { 子宮 } 70 \mathrm{mg} \\
& \text { 中段 去勢まう } \\
& \text { す子宮 } 20 \mathrm{mg} \\
& \text { 下段 耳静脈血 } \\
& \text { 清え一てる可 } \\
& \text { 溶性成分注射 } \\
& \text { 去勢まうす子 } \\
& \text { 宮 } 24 \mathrm{mg}
\end{aligned}
$$

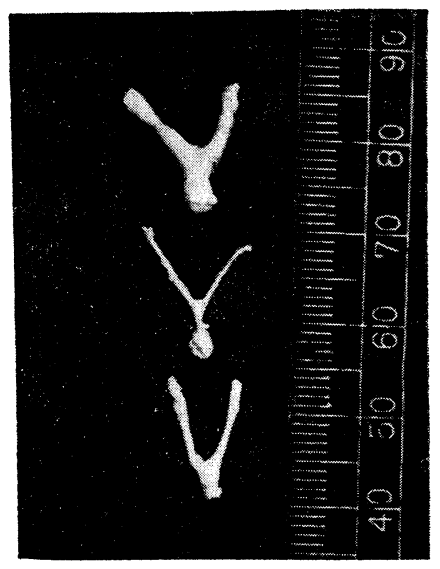

(5) (114倍撗大, H. E. 染色) 去勢まうす子宮”。 粘膜像

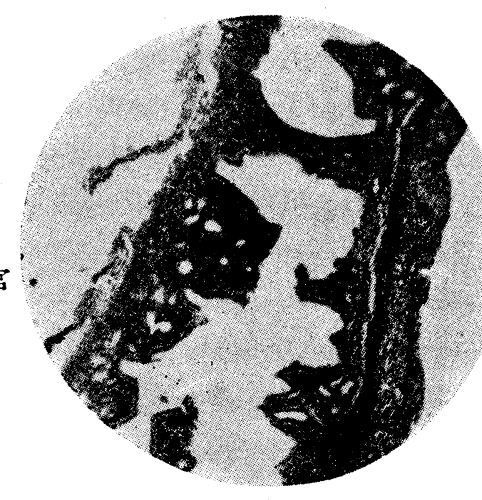

(6) (114倍演大, H. E. 染色)

子宮静脈血清元 一てる可溶性成 分注射去勢まう す子宮粘膜像

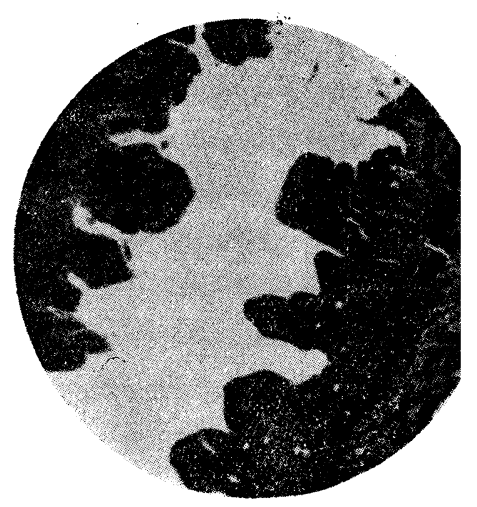

